\title{
GABA Transmission in the Nucleus Accumbens Is Altered after Withdrawal from Repeated Cocaine
}

\author{
Zheng-Xiong Xi, Sammanda Ramamoorthy, Hui Shen, Russell Lake, Devadoss J. Samuvel, and Peter W. Kalivas \\ Department of Physiology and Neuroscience, Medical University of South Carolina, Charleston, South Carolina 29425
}

Repeated cocaine causes enduring changes in dopamine and glutamate transmission in the nucleus accumbens, and dopamine and glutamate terminals synapse on GABAergic accumbens neurons. The present study demonstrates that there are changes in GABA transmission in the accumbens at 3 weeks after discontinuing daily cocaine injections. No-net flux microdialysis revealed a significant increase in the basal levels of extracellular GABA in the accumbens of cocaine-treated rats. The elevated extracellular GABA was normalized by blocking voltage-dependent $\mathrm{Na}^{+}$channels and provided increased tone on $\mathrm{GABA}_{\mathrm{B}}$ presynaptic autoreceptors and heteroreceptors because blocking $\mathrm{GABA}_{\mathrm{B}}$ receptors produced a greater elevation in extracellular $\mathrm{GABA}$, dopamine, and glutamate in cocaine-treated compared with control subjects. For many G-protein-coupled receptors, increased agonist can cause receptor desensitization. Consistent with $\mathrm{GABA}_{\mathrm{B}}$ receptor desensitization, baclofen-stimulated GTP $\gamma S$ binding was reduced, and the reduction in G-protein coupling was accompanied by reduced Ser phosphorylation of the $\mathrm{GABA}_{\mathrm{B} 2}$ receptor subunit. No effect by repeated cocaine was found in the levels of total $\mathrm{GABA}_{\mathrm{B} 1}$ or $\mathrm{GABA}_{\mathrm{B} 2}$ protein. Together, these data demonstrate that withdrawal from repeated cocaine treatment produces an increase in the basal levels of extracellular GABA in the accumbens that depends on neuronal activity. The increase may be mediated in part by functional desensitization of $\mathrm{GABA}_{\mathrm{B}}$ receptors, likely the result of diminished Ser phosphorylation of the $\mathrm{GABA}_{\mathrm{B} 2}$ receptor.

Key words: GABA; cocaine; immunoblot; phosphorylation; microdialysis; glutamate

\section{Introduction}

Research during the past decade shows that repeated cocaine administration causes a number of alterations in dopamine and glutamate transmission in the nucleus accumbens that may be linked to addiction (Vanderschuren and Kalivas, 2000; Nestler, 2001). These studies are in accord with experiments that point to the accumbens as a critical substrate for both drug reward and the expression of behaviors indicative of cocaine addiction (Everitt and Wolf, 2002). Dopamine and glutamate terminals synapse on GABAergic spiny cells in the nucleus accumbens (Sesack and Pickel, 1990), and spiny cell axons collateralize to provide GABAergic innervation of near adjacent spiny neurons (Pennartz et al., 1994). In addition, there are dense GABAergic afferents to the accumbens, as well as a small population of GABAergic interneurons (Brog et al., 1993; Pennartz et al., 1994). Despite the central physiological role played by GABA in the accumbens, compared with glutamate and dopamine, there is relatively less information on the capacity of repeated cocaine to produce neuroadaptations in accumbens GABA transmission, especially at late withdrawal times when many addiction-related behaviors, such as sensitization, craving, and paranoia continue to be expressed. Understanding long-lasting interactions between repeated cocaine and GABA transmission is especially important, because the cocaine-induced changes in gene expression in GABAergic spiny cells are mediated by dopamine and glutamate and are hypothesized to be primary adaptive events in the development and expression of addiction (Nestler, 2001). Also, there is evidence for recipro-

\footnotetext{
Received Dec. 19, 2002; revised Jan. 29, 2003; accepted Jan. 30, 2003.

This work was supported in part by United States Public Health Service Grants MH-40817 (P.W.K.), DA-03906 (P.W.K.), and MH-62612 (S.R.).

Correspondence should be addressed to Dr. Peter Kalivas, Department of Physiology and Neuroscience, Medical University of South Carolina, 173 Ashley Avenue, Suite BSB 403, Charleston, SC 29425. E-mail: kalivasp@musc.edu. Copyright $\odot 2003$ Society for Neuroscience $\quad 0270-6474 / 03 / 233498-08 \$ 15.00 / 0$
}

cal presynaptic modulation between GABA, dopamine, and glutamate in the accumbens (Harsing and Zigmond, 1997; Schoffelmeer et al., 2000), posing a role for altered GABA transmission in mediating the cocaine-induced adaptations in dopamine and glutamate transmission (Everitt and Wolf, 2002).

The present study evaluated the possibility that repeated cocaine combined with 3 weeks of withdrawal alters in vivo presynaptic GABA transmission in the accumbens. Microdialysis was used to demonstrate that the basal levels of extracellular GABA are elevated by repeated cocaine. This observation generated two additional hypotheses. (1) The elevated basal GABA levels result from a decreased capacity of $\mathrm{GABA}_{\mathrm{B}}$ autoreceptors to regulate GABA release. Previous studies supporting this possibility include repeated amphetamine treatment decreases G-protein coupling of $\mathrm{GABA}_{\mathrm{B}}$ receptors in the accumbens (Zhang et al., 2000) and repeated cocaine decreases the electrophysiological impact of $\mathrm{GABA}_{\mathrm{B}}$ receptor stimulation in the lateral septum (Shoji et al., 1997). (2) Elevated extracellular GABA provides increased tone on presynaptic $\mathrm{GABA}_{\mathrm{B}}$ heteroreceptors that decreases the basal level of glutamate. Previous studies have shown a decrease in basal extracellular levels of glutamate in the accumbens after repeated cocaine (Pierce et al., 1996; Hotsenpiller et al., 2001). Also, repeated amphetamine treatment enhances tonic modulation of $\mathrm{GABA}_{\mathrm{B}}$ receptors regulating dopamine and glutamate release in the ventral tegmental area (Giorgetti et al., 2002). To evaluate these hypotheses, the level of $\mathrm{GABA}_{\mathrm{B}}$ receptor protein and phosphoprotein was measured, as was the efficiency of G-protein coupling. Also, in vivo microdialysis was used to examine the capacity of $\mathrm{GABA}_{\mathrm{B}}$ receptors to regulate the extracellular levels of glutamate and dopamine.

\section{Materials and Methods}

Animals housing and surgery. All experiments were conducted according to specifications of the National Institute of Health guide for the Care and 
Use of Laboratory Animals. Male Sprague Dawley (Raleigh, NC) rats, weighing between 250 and $300 \mathrm{gm}$, were individually housed and maintained on a $12 \mathrm{hr}$ light/dark cycle (7:00 A.M., 7:00 P.M.) with access to food and water ad libitum. All experimentation was conducted during the light period. Using ketamine $(100 \mathrm{mg} / \mathrm{kg})$ and xylazine $(3 \mathrm{mg} / \mathrm{kg})$ anesthesia, dialysis guide cannulas (20 gauge, $14 \mathrm{~mm}$; Small Parts, Roanoke, VA) were implanted over the nucleus accumbens [+1.6 mm anterior to bregma, $\pm 1.6 \mathrm{~mm}$ mediolateral, and $-4.7 \mathrm{~mm}$ ventral to the skull surface, according to the atlas of Paxinos and Watson (1986)] using a $6^{\circ}$ angle from vertical. The guide cannulas were fixed to the skull with four stainless steel skull screws (Small Parts) and dental acrylic.

Repeated cocaine treatment. Cocaine was donated by the National Institute on Drug Abuse. One week after arrival in the animal facility, rats were treated with either cocaine $(15 \mathrm{mg} / \mathrm{kg}$, i.p. $)$ or the same volume $(1.0$ $\mathrm{ml} / \mathrm{kg}$, i.p.) of saline (day 1 ). On days $2-6$ the rats received saline or 30 $\mathrm{mg} / \mathrm{kg}$ cocaine and, on day 7 , received $15 \mathrm{mg} / \mathrm{kg}$ cocaine. Brain dissection or microdialysis was performed after 3 weeks withdrawal from the last saline or cocaine injection. This treatment regimen has been shown previously to produce enduring behavioral sensitization and changes in extracellular glutamate levels (Pierce et al., 1996). In addition, examining 3 weeks of withdrawal potentially provides a better estimate of the neuroadaptations mediating the long-lasting behavioral effects of cocaine (for review, see White and Kalivas, 1998; Wolf, 1998).

Microdialysis. Dialysis probes were constructed as described by Robinson and Whishaw (1988) with some modifications (including using smaller silica tubing). The active region of the dialysis membrane is $0.8-$ $1.5 \mathrm{~mm}$ in length and $\sim 175 \mu \mathrm{m}$ in diameter Probes were inserted into the accumbens at least $12 \mathrm{hr}$ before the experiment to minimize the effects of damage-induced dopamine and glutamate release during the experiment. On the day of the experiment, dialysis buffer ( $5 \mathrm{~mm}$ glucose, 2.5 $\mathrm{mm} \mathrm{KCl}, 140 \mathrm{~mm} \mathrm{NaCl}, 1.4 \mathrm{~mm} \mathrm{CaCl}_{2}, 1.2 \mathrm{mM} \mathrm{MgCl}_{2}$, and $0.15 \% \mathrm{PBS}$, pH 7.4) was perfused through the probe $(2.0 \mu \mathrm{l} / \mathrm{min})$ for at least $2 \mathrm{hr}$ before sample collection. Dialysis samples were collected every $20 \mathrm{~min}$ into $10 \mu \mathrm{l}$ of dialysis buffer (for glutamate and GABA) or mobile phase (for dopamine) containing an internal standard.

The $\mathrm{GABA}_{\mathrm{B}}$ agonist $R(+)$-baclofen and the $\mathrm{GABA}_{\mathrm{B}}$ antagonist 2-OHsaclofen were purchased from Tocris Cookson (Ballwin, MO). GABA and tetrodotoxin (TTX) were purchased from Sigma (St. Louis, MO). Both baclofen and 2-OH-saclofen were initially dissolved in 1 equivalent $\mathrm{NaOH}$ (Sigma) and neutralized with $0.1 \mathrm{~N} \mathrm{HCl}$ (Sigma) to a concentration of $10^{-2}$ M. Other drugs are directly dissolved in filtered dialysis buffer. Working concentrations were then made by diluting with filtered buffer.

Quantification of GABA. The concentration of GABA in each sample was determined using a modified "Fast Analysis of GABA" provided by ESA (Bedford, MA). The dialysis samples were collected into $10 \mu \mathrm{l}$ of dialysis buffer (plus $40 \mu \mathrm{l}$ of sample in $20 \mathrm{~min}$ ) containing DL- $\alpha$-amino$n$-butyric acid (DL-ABA) as the internal standard for GABA. Methanol (15\%) mobile phase containing $100 \mathrm{~mm} \mathrm{NaH} \mathrm{PO}_{4}, \mathrm{pH} 4.6$, and a reversed-phase column $(4.6 \times 80,3 \mu \mathrm{m}$; model HR-80; Bioanalytical Systems, West Lafayette, IN) were used to separate the amino acids. A coulometric electrochemical detection system using three electrodes [preinjection guard electrode, $+0.7 \mathrm{~V}$; reduction electrode 1 (E1), $0.4 \mathrm{~V}$; reduction electrode $2(\mathrm{E} 2), 0.65 \mathrm{~V}$ ] was used for quantification. Area under the curve of the GABA and DL-ABA peaks was measured with an ESA 501 Chromatography Data System. GABA values were normalized to the internal standard DL-ABA and compared with an external standard curve for quantification.

Quantification of glutamate. Glutamate in the dialysis sample was measured using an HPLC system with fluorescent detector. The dialysis samples were collected into $10 \mu \mathrm{l}$ of $0.05 \mathrm{M} \mathrm{HCl}$ containing 2 pmol of homoserine as an internal standard. The mobile phase consisted of $13 \%$ acetylnitrile (v/v), $100 \mathrm{~mm} \mathrm{NaH}_{2} \mathrm{PO}_{4}$, and $0.1 \mathrm{~mm}$ EDTA, pH 6.0. A reversed-phase column $(10 \mathrm{~cm}, 3 \mu \mathrm{m}$ C- 18 reversed phase; Bioanalytical Systems) was used to separate the amino acids, and precolumn derivatization of amino acids with $o$-phthalaldehyde was performed using an ESA model 540 autosampler. Glutamate was detected by a fluorescence spectrophotometer (LINEAR FLOUR LC 305; ESA) using an excitation wavelength of $336 \mathrm{~nm}$ and an emission wavelength of $420 \mathrm{~nm}$. Glutamate content in each sample was quantified with the ESA 501 Chromatography Data System.

Quantification of dopamine. For the measurement of extracellular dopamine, samples were collected into $10 \mu \mathrm{l}$ of mobile phase $(4.76 \mathrm{~mm}$ citric acid, $150 \mathrm{~mm} \mathrm{NaH}_{2} \mathrm{PO} 4,50 \mu \mathrm{m}$ EDTA, $3 \mathrm{~mm}$ SDS, $10 \%$ methanol $(\mathrm{v} / \mathrm{v})$, and $15 \%$ acetylnitrile $(\mathrm{v} / \mathrm{v}), \mathrm{pH} 5.6$, plus $2.0 \mathrm{pmol}$ of dihydroxybenzylamine as an internal standard), and all samples were frozen at $-80^{\circ} \mathrm{C}$. The samples were subsequently thawed and placed in an ESA model 540 autosampler connected to an HPLC system with electrochemical detection. Dopamine was separated using a $10 \mathrm{~cm}$ C18 reversedphase column (Bioanalytical Systems) and oxidized-reduced using coulometric detection (ESA). Three electrodes were used: a preinjection port guard cell $(+0.4 \mathrm{~V})$ to oxidize the mobile phase, an oxidation analytical electrode $(\mathrm{E} 1,-0.1 \mathrm{~V})$, and a reduction analytical electrode $(\mathrm{E} 2,+0.2 \mathrm{~V})$. The area under curve of the dopamine peak was measured with ESA 501 Chromatography Data System. Dopamine values were normalized to the internal standard dihydroxybenzylamine and compared with an external standard curve for quantification.

$\left[{ }^{35} S\right]$ GTP $\gamma S$ binding assay. Membrane proteins were prepared according to the method described by Sim et al. (1996). Three weeks after cocaine or saline pretreatment, the nucleus accumbens (core and shell) was removed and homogenized in $20 \mathrm{vol}$ of buffer containing $50 \mathrm{~mm}$ Tris- $\mathrm{HCl}, 3 \mathrm{~mm} \mathrm{MgCl}_{2}$, and $1 \mathrm{~mm}$ EGTA, $\mathrm{pH}$ 7.4. The homogenate was centrifuged twice at $48,000 \times \mathrm{g}$ at $4^{\circ} \mathrm{C}$ for $10 \mathrm{~min}$ and resuspended in assay buffer ( $50 \mathrm{~mm}$ Tris- $\mathrm{HCl}, 3 \mathrm{~mm} \mathrm{MgCl}_{2}, 0.2 \mathrm{~mm}$ EGTA, and $100 \mathrm{~mm}$ $\mathrm{NaCl}, \mathrm{pH}$ 7.4). Proteins were assayed by using the Bio-Rad (Hercules, CA) DC protein assay and then stored at $-80^{\circ} \mathrm{C}$ for binding assay.

The $\left[{ }^{35} \mathrm{~S}\right] \mathrm{GTP} \gamma \mathrm{S}$ binding assay was modified from the procedures described by Schaffhauser et al. (2000). Briefly, $12 \times 75 \mathrm{~mm}$ polystyrene test tubes had $1 \mathrm{ml}$ of assay buffer containing $30 \mu \mathrm{g}$ of proteins, $30 \mu \mathrm{M}$ GDP, $1 \mathrm{U}$ of adenosine deaminase, $0.1 \mathrm{~nm}\left[{ }^{35} \mathrm{~S}\right] \mathrm{GTP} \gamma \mathrm{S}$ (Amersham Biosciences, Arlington Heights, IL), and various concentrations of baclofen $\left(10^{-8}\right.$ to $\left.10^{-4} \mathrm{M}\right)$. Basal binding was measured in the absence of agonist, and nonspecific binding was measured in the presence of $10 \mu \mathrm{M}$ unlabeled GTP $\gamma \mathrm{S}$. The reaction was then terminated by filtration under vacuum through Whatman (Maidstone, UK) GF/B glass fiber filters, followed by three washes with cold Tris-HCl buffer. After transfer of the filters into glass vials containing $10 \mathrm{ml}$ of Ecolite scintillation fluid, the radioactivity was measured by liquid scintillation spectrophotometry. Data are represented as mean \pm SEM of three experiments, each performed in duplicate.

$G A B A_{B}$ immunoblotting. Three weeks after the last daily injection of saline or cocaine, rats were decapitated, and the brains were rapidly removed and dissected into coronal sections on ice. The nucleus accumbens (containing both core and shell) was dissected on an ice-cooled Plexiglas plate using a 15 gauge tissue punch. Brain punches were immediately frozen on dry ice and stored at $-80^{\circ} \mathrm{C}$ until homogenized for immunoblotting.

The dissected brain punches were homogenized with a hand-held tissue grinder in a buffer containing $100 \mathrm{~mm}$ Tris, pH 7.4, $150 \mathrm{~mm} \mathrm{NaCl}, 1$ mM EDTA, $0.1 \%$ SDS, $1 \%$ Triton X-100, $1 \mu \mathrm{g} / \mathrm{ml}$ aprotinin, $1 \mu \mathrm{g} / \mathrm{ml}$ leupeptin, $1 \mu \mathrm{M}$ pepstatin, $1 \mathrm{mg} / \mathrm{ml}$ soybean trypsin inhibitors, $1 \mathrm{~mm}$ iodoacetimide, $250 \mu \mathrm{M}$ PMSF, sodium fluoride, sodium pyrophosphate, sodium orthovanadate, and okadaic acid. Insoluble materials were removed from lysates by centrifugation at $22,000 \times \mathrm{g}$ for $20 \mathrm{~min}$ at $4^{\circ} \mathrm{C}$. Protein determinations were performed using the Bio-Rad DC protein assay according to the instructions of the manufacturer. Samples $(30 \mu \mathrm{g})$ were subjected to SDS-PAGE (8\%) using a mini-gel apparatus (Bio$\mathrm{Rad})$, transferred via semidry apparatus (Bio-Rad) to nitrocellulose membrane, and probed for the proteins of interest (one gel per protein per brain region). $\mathrm{GABA}_{\mathrm{B}}$ receptors were identified using a rabbit antirat antibody against $\mathrm{GABA}_{\mathrm{B} 1}$ (1:2000) or guinea pig anti-rat antibody against $\mathrm{GABA}_{\mathrm{B} 2}$ receptor (1:2000) purchased from Chemicon (Temecula, CA) that was made against a peptide containing the $C$ terminus of $G_{A B A}$ or $\mathrm{GABA}_{\mathrm{B} 2}$ subunit. In control experiments, a synthesized peptide having the same 21 amino acid sequence on the C-terminal of $G_{A B A}$ was used to competitively inhibit the binding of antibody to $\mathrm{GABA}_{\mathrm{B} 1}$. Skeletal muscle extract was used as a negative control for $\mathrm{GABA}_{\mathrm{B} 2}$ receptor-specific detection. Labeled proteins were detected using an HRP-conjugated anti-rabbit 
secondary IgG diluted 1:30,000 (Upstate Biotechnology, Lake Placid, NY) or goat anti-guinea pig secondary IgG diluted 1:10,000 (Jackson ImmunoResearch, West Grove, PA) and visualized with enhanced chemiluminescence (Amersham Biosciences). Assurance of even transfer and equal amount of protein loading was evaluated with Ponceau S (Sigma), followed by destaining with de-ionized water, and the blots were reprobed with anti-calnexin (BD Transduction Laboratories, Lexington, KY). Blots were stripped (62.5 $\mathrm{mm}$ Tris-HCl, pH 6.8, 2\% SDS, and $100 \mathrm{~mm} \beta$-mercaptoethanol) for $30 \mathrm{~min}$ at $50^{\circ} \mathrm{C}$, washed with PBS twice for $10 \mathrm{~min}$, reblocked in $5 \%$ dry milk for $1 \mathrm{hr}$, and probed with anti-calnexin (1:2000; BD Transduction Laboratories), followed by goat anti-rabbit HRP-conjugated secondary antibody $(1: 10,000)$. In no gel did calnexin density indicate differences in protein loading (for representative calnexin immunostaining, see Fig. 6A). Immunoreactive levels were quantified by integrating band density $X$ area using computerassisted densitometry (NIH Image version 1.60). $\mathrm{GABA}_{\mathrm{B}}$ densities were divided by the corresponding calnexin densities. The resulting values were averaged over three control samples for each gel, and all bands were normalized as percentage of the control values.

Immunoprecipitation of $G A B A_{B 2}$. Brain tissues were homogenized in cold radioimmunoprecipitation assay (RIPA) buffer containing $100 \mathrm{~mm}$ Tris, $\mathrm{pH}$ 7.4, $150 \mathrm{~mm} \mathrm{NaCl}, 1$ mм EDTA, 0.1\% SDS, 1\% Triton X-100, and $1 \%$ sodium deoxycholate, supplemented with protease inhibitors (1 $\mu \mathrm{g} / \mathrm{ml}$ aprotinin, $1 \mu \mathrm{g} / \mathrm{ml}$ leupeptin, $1 \mu \mathrm{M}$ pepstatin, $1 \mathrm{mg} / \mathrm{ml}$ soybean trypsin inhibitors, $1 \mathrm{~mm}$ iodoacetimide, and $250 \mu \mathrm{M}$ PMSF). Phosphatase inhibitors such as sodium fluoride, sodium pyrophosphate, sodium orthovanadate, and okadaic acid were used in RIPA buffer to preserve the phosphorylation state of $\mathrm{GABA}_{\mathrm{B} 2}$ receptor proteins. Receptor proteins were immunoprecipitated from $400 \mu \mathrm{g}$ of extract overnight at $4^{\circ} \mathrm{C}$ by the addition of the specific antibodies against $\mathrm{GABA}_{\mathrm{B} 2}$ (3 $\mu \mathrm{g}$; Chemicon), followed by $3 \mathrm{hr}$ incubation at $4^{\circ} \mathrm{C}$ with Protein A Sepharose beads $(3 \mathrm{mg}$ in $100 \mu \mathrm{l}$ of RIPA buffer). The immunoprecipitates were washed three times with RIPA buffer, and the immunoprecipitated proteins were eluted and subjected to SDS-PAGE (8\%). Immunoblotting was performed using phospho (p)-Ser-specific monoclonal antibodies (1:1000; Chemicon). To verify that the identified band was a phosphoprotein, the blots were stripped as described above and incubated with phosphatase ( $5 \mathrm{U}$ ) in $50 \mathrm{~mm}$ Tris- $\mathrm{HCl}, \mathrm{pH} 9.3$, and $1 \mathrm{~mm} \mathrm{MgCl} 2$ for $6 \mathrm{hr}$ at $37^{\circ} \mathrm{C}$. The blots were washed and probed with p-Ser antibody. Also, in a separate experiment, nucleus accumbens extracts from control subjects were treated with phosphatase $(5 \mathrm{U})$ at $37^{\circ} \mathrm{C}$ for $6 \mathrm{hr}$, followed by immunoprecipitation and Western analysis with p-Ser antibody. The previously observed immunoreactivity of $\mathrm{p}-\mathrm{GABA}_{\mathrm{B} 2}$ was absent, suggesting that assay is detecting $\mathrm{p}-\mathrm{GABA}_{\mathrm{B} 2}$ receptors. Immunoblots with p-Ser-specific antibodies from immunoprecipitated $\mathrm{GABA}_{\mathrm{B}}$ receptors were quantified using computer-assisted densitometry (NIH Image version 1.60).

Histology. After the dialysis experiments, rats were administered an overdose of pentobarbitol $(>100 \mathrm{mg} / \mathrm{kg}$, i.p. $)$ and transcardially perfused with $0.9 \%$ saline, followed by $10 \%$ Formalin solution. Brains were removed and placed in 10\% Formalin for at least 1 week to ensure proper fixation. The tissue was blocked, and coronal sections (100 $\mu \mathrm{m}$ thick) were made through the site of dialysis probe with a vibratome. The brains were then stained with cresyl violet to verify anatomical placement according to the atlas of Paxinos and Watson (1986).

Statistical analysis. The StatView statistics package was used to estimate statistical significance. A one-way ANOVA with repeated measures over dose was used to determine the effect of individual drugs on extracellular dopamine, glutamate, or GABA levels. A two-way ANOVA with repeated measures over time or dose was used to compare between treatments. During identification of statistical significance, post hoc comparisons were made with a Fischer's PLSD test.

\section{Results \\ Cocaine withdrawal elevates the basal levels of extracellular GABA}

The in vivo basal levels of extracellular GABA in the nucleus accumbens were determined using no-net flux microdialysis (Parsons et al., 1991). After collecting five 20 min samples different concentrations of GABA $(2.525,50,100 \mathrm{nM})$ were passed

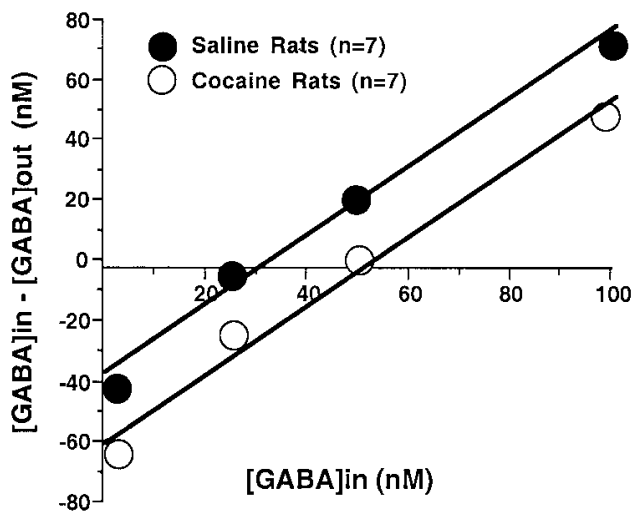

Figure 1. No-net flux microdialysis showing the increase in basal level of extracellular GABA in the accumbens in chronic cocaine- versus saline-treated rats. After collecting five $20 \mathrm{~min}$ baseline samples, 2.5, 25, 50, and $100 \mathrm{~nm}$ GABA was added to the dialysis buffer, and the net loss or gain in GABA in the collected dialysis buffer was quantified. The resulting linear equation estimates the basal level of extracellular GABA (concentration of no-net flux, i.e., $y=0$ ) and the rate of elimination of GABA from the extracellular space (i.e., the slope of the line) in each subject (Parsons et al., 1991). The average of the basal levels of extracellular GABA was significantly increased in chronic cocaine-treated rats ( $32.7 \pm 4.0$ in saline-treated rats vs $50.3 \pm 6.6$ in cocaine-treated rats; a two-tail Student's t test; $p<0.05$ ), whereas the elimination rates of GABA from extracellular space (the slopes) were not different (1.14 \pm 0.08 in saline-treated rats vs $1.19 \pm 0.05$ in chronic cocaine-treated rats).

through the dialysis probe permitting extrapolation to the concentration of no net GABA flux across the dialysis membrane, which corresponds to the basal extracellular concentration. The slope of the line reflects the relative activity of processes eliminating GABA from the extracellular space by uptake, diffusion and enzymatic degradation. Figure 1 reveals a significant increase in the basal level of GABA from $32.7 \pm 4.0 \mathrm{~nm}$ in saline rats to $50.3 \pm$ $6.6 \mathrm{nM}$ in cocaine-treated subjects after 3 weeks withdrawal. In contrast, the slopes of the two lines were statistically equivalent indicating no difference in GABA elimination from the extracellular space.

\section{Increased extracellular GABA by chronic cocaine is from neurons}

To determine the source of the extracellular GABA, voltagedependent ion channel blockers were infused into the nucleus accumbens. Figure $2 \mathrm{~A}$ shows that blockade of the voltagedependent $\mathrm{Na}^{+}$channel by TTX $(1 \mu \mathrm{M})$ or $\mathrm{Ca}^{2+}$ channels by either $\omega$-conotoxin GVIA (N-type blocker) or $\omega$-conotoxin MVIIC (P/Q-type blocker) lowered the basal levels of extracellular GABA by $\sim 25 \%$. This is consistent with other studies showing that the majority of extracellular GABA measured by microdialysis was not derived from neuronal or vesicular pools (for review, see Timmerman and Westerink, 1997).

In contrast to the basal levels of extracellular GABA in control subjects, Figure $2 B$ shows that the elevated extracellular GABA associated with cocaine-treated subjects was reduced substantially by $1 \mu \mathrm{M}$ TTX and approached the level of extracellular GABA in control subjects. Increasing the dose from 1 to $10 \mu \mathrm{M}$ TTX failed to produce additional reductions in extracellular GABA in either treatment group.

\section{Enhanced GABA tone on $\mathrm{GABA}_{\mathrm{B}}$ autoreceptors and heteroreceptors by chronic cocaine}

Figure 3 shows that reverse dialysis of the $\mathrm{GABA}_{\mathrm{B}}$ receptor antagonist 2-OH-saclofen into the accumbens elevated the extracellular content of GABA, dopamine, and glutamate in cocaine- 

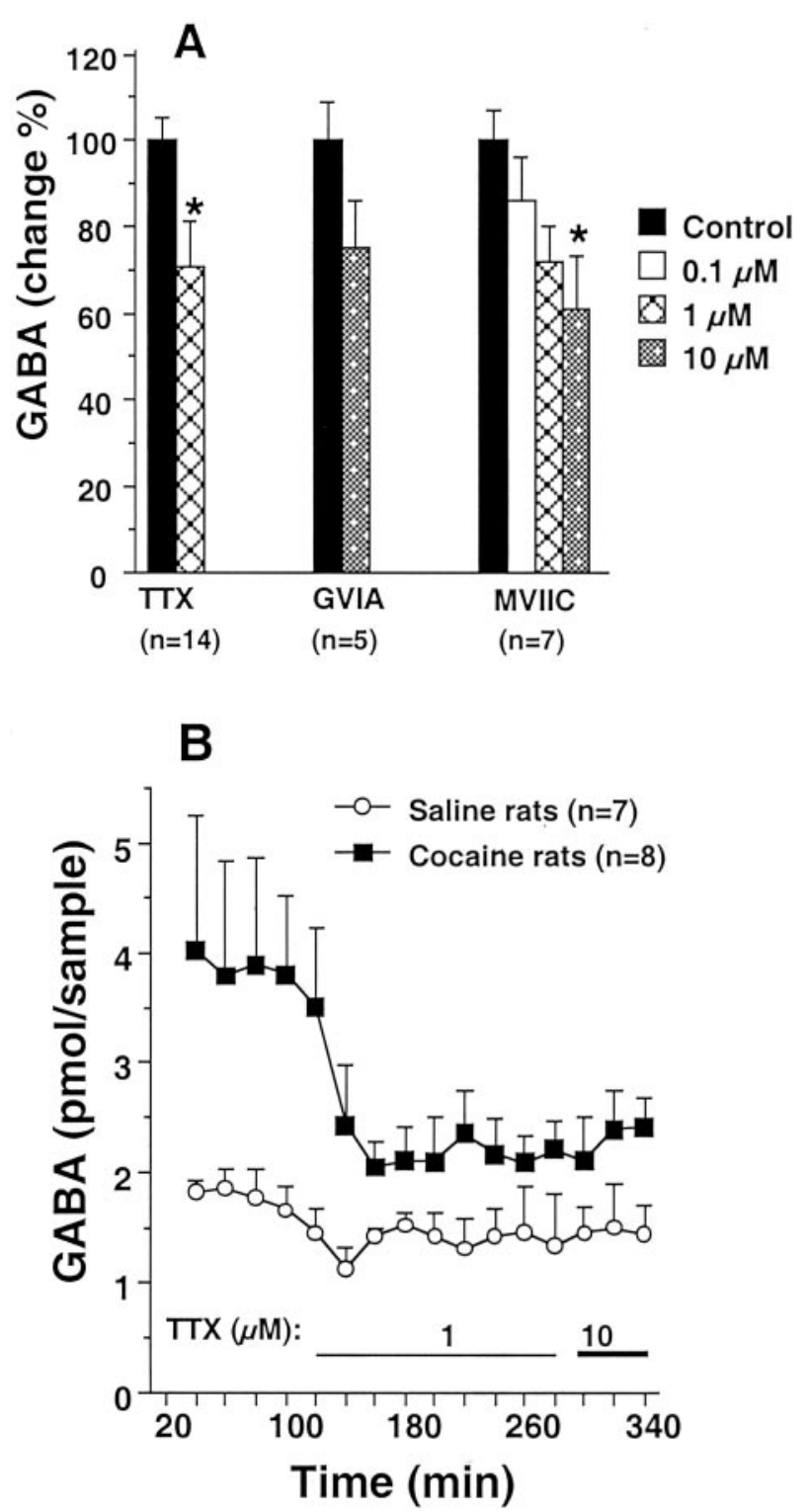

Figure 2. Blockade of the voltage-dependent $\mathrm{Na}^{+}$channels markedly reduces the elevated GABA levels measured after repeated cocaine treatment. $A$ shows that the basal levels of extracellular GABA in control subjects is only marginally reduced by TTX ( $\mathrm{Na}^{+}$channel blocker), $\omega$-conotoxin GVIA (GVIA; N-type $\mathrm{Ca}^{2+}$ channel blocker), or $\omega$-conotoxin MVIIC (MVIIC; P/Qtype $\mathrm{Ca}^{2+}$ channel blocker). The value in each column represents the average of three $20 \mathrm{~min}$ dialysis samples collected for each drug or dose. $B$ shows that blockade of the voltagedependent $\mathrm{Na}^{+}$channels by TTX reversed the increase in extracellular GABA observed in chronic cocaine-treated rats. A two-way ANOVA with repeated measurements revealed a significant difference between the treatment (chronic saline vs cocaine) $\left(F_{(1,12)}=6.62 ; p=\right.$ $0.025)$ and a significant interaction between treatment and time $\left(F_{(16,192)}=3.85 ; p=\right.$ $0.0001) .{ }^{*} p<0.05$ compared with the average of the baseline samples (Control).

treated rats. In contrast, in saline-treated subjects, much lower GABA tone was evident on $\mathrm{GABA}_{\mathrm{B}}$ presynaptic receptors. Reverse dialysis of 2-OH-saclofen produced no effect on the extracellular levels of dopamine or glutamate in control animals, whereas relatively small increases were measured in extracellular GABA. The repeated cocaine treatment group had elevated basal levels of GABA $(1.40 \pm 0.23 \mathrm{pmol} /$ sample for saline; $2.22 \pm 0.24$ for cocaine; $p<0.05)$ and reduced basal levels of extracellular glutamate $(115.4 \pm 20.4 \mathrm{pmol} / \mathrm{sample}$ for saline; $72.6 \pm 12.6$ for cocaine; $p<0.05)$. In contrast the basal levels of dopamine were not significantly altered by repeated cocaine $(36.8 \pm 6.0 \mathrm{fmol} /$ sample for saline; $25.6 \pm 7.6$ for cocaine).

In contrast to the differential effects produced by antagonizing $\mathrm{GABA}_{\mathrm{B}}$ autoreceptors and heteroreceptors in repeated cocaine and saline animals, stimulating $\mathrm{GABA}_{\mathrm{B}}$ receptors with baclofen produced approximately equivalent reductions in the extracellular content of GABA, glutamate, or dopamine in both treatment groups (Fig. 4). The basal levels of extracellular GABA were significantly elevated in the repeated cocaine group (1.30 \pm $0.29 \mathrm{pmol} / \mathrm{sample}$ for saline; $2.16 \pm 0.24$ for cocaine; $p<0.05$ ), whereas the basal levels of neither glutamate $(135.6 \pm 17.8 \mathrm{pmol} /$ sample for saline; $102.8 \pm 20.2$ for cocaine) nor dopamine (28.2 $\pm 5.2 \mathrm{fmol} / \mathrm{sample}$ for saline; $22.8 \pm 4.4$ for cocaine) were significantly affected.

\section{Repeated cocaine reduces the functional capacity of $\mathrm{GABA}_{\mathrm{B}}$ receptors}

Elevated levels of extracellular GABA could arise from desensitization of $\mathrm{GABA}_{\mathrm{B}}$ receptors. To evaluate this possibility, the coupling of $\mathrm{GABA}_{\mathrm{B}}$ receptors to intracellular G-proteins was determined by measuring baclofen-stimulated GTP $\gamma \mathrm{S}$ binding in membranes obtained from the accumbens of cocaine- and salinetreated rats. Figure 5 shows that baclofen elicited a dosedependent increase in $\left[{ }^{35} \mathrm{~S}\right] \mathrm{GTP} \gamma \mathrm{S}$ binding to G-proteins in both saline- and cocaine-treated rats. However, the maximum stimulation of binding was significantly reduced in the cocaine-treated subjects.

\section{$\mathrm{GABA}_{\mathrm{B} 1}$ and $\mathrm{GABA}_{\mathrm{B} 2}$ receptors}

Figure $6 A$ shows a representative immunoblot of $\mathrm{GABA}_{\mathrm{B} 2}$ protein in the nucleus accumbens. There was no significant difference in the levels of total $\mathrm{GABA}_{\mathrm{B} 2}$ protein between the cocaine and saline treatment groups (Fig. 6C). Similar to observations made by Couve et al. (2002) in neuronal cultures, the $\mathrm{GABA}_{\mathrm{B} 2}$ receptor is substantially Ser-phosphorylated in vivo. Cocaine treatment markedly reduced the amount of Ser-phosphorylated $\mathrm{GABA}_{\mathrm{B} 2}\left(\mathrm{p}-\mathrm{GABA}_{\mathrm{B} 2}\right)$ measured in the nucleus accumbens (Fig. $6 B, C)$. Figure $6 B$ also shows the results of reprobing the blot with p-Ser antibody after stripping and incubating with phosphatase. The lack of immunostaining verifies that the original staining was a phosphoprotein.

Akin to the $\mathrm{GABA}_{\mathrm{B} 2}$ subunit, there was no difference in total $\mathrm{GABA}_{\mathrm{B} 1}$ protein content between saline- and cocaine-treated subjects (Fig. $6 D$ ). The amount of p-GABA $\mathrm{B}_{1}$ was not sufficient to quantify in either cocaine or saline animals (data not shown).

\section{Histology}

All dialysis probe placements used for data analysis had $>50 \%$ of the active membrane within the boundaries of the nucleus accumbens, as defined by Paxinos and Watson (1986). The probe placements were generally at the interface between the core and shell compartments of the nucleus accumbens. When a portion of the probe was outside the nucleus accumbens, it was in the ventrolateral septum, ventromedial diagonal band of Broca, or ventromedial striatum.

\section{Discussion}

The present study demonstrates that, 3 weeks after discontinuing treatment with repeated cocaine injections, the basal level of extracellular GABA in the nucleus accumbens is increased. Because the $\mathrm{Na}^{+}$channel blocker TTX substantially reduced the increase in basal extracellular GABA, the majority of the increase in cocaine-treated subjects is derived from a neuronal source. 
A GABA

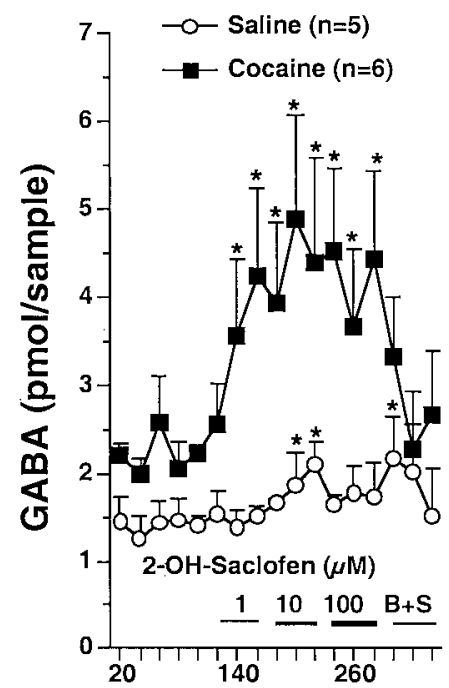

B Dopamine

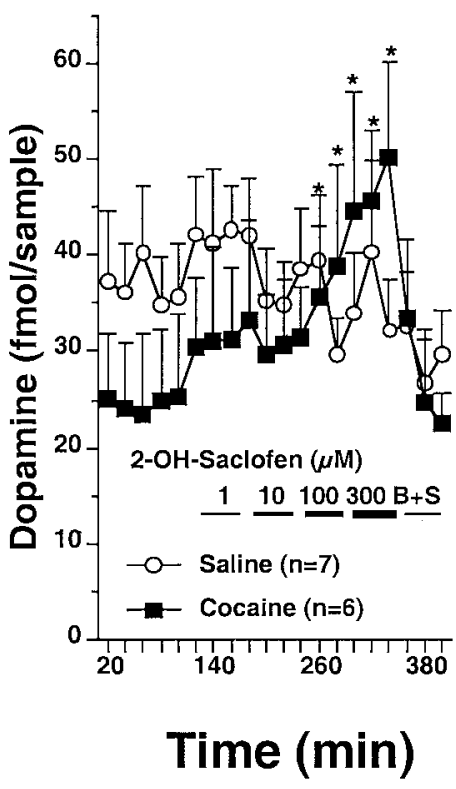

C Glutamate

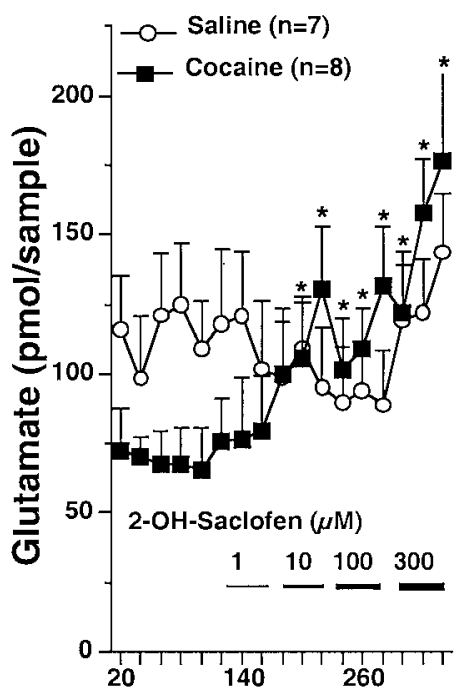

Figure 3. Blockade of $\mathrm{GABA}_{B}$ receptors by 2-OH-saclofen produced an enhanced elevation of extracellular $\mathrm{GABA}(A)$, dopamine ( $B$ ), and glutamate $(C)$ in the nucleus accumbens of chronic cocaine-treated rats. Increasing concentrations of 2-OH-saclofen were added to the dialysis buffer, and, in some experiments, $300 \mu \mathrm{m}$ baclofen was added to the final concentration of 2-0H-saclofen to reverse the $G A B A_{B}$ receptor blockade $(B+S)$. A two-way ANOVA with repeated measurements over dose reveals a significant effect of baclofen dose $\left(F_{(16,128)}=3.44, p=0.0001\right.$ for $G A B A$ in $A$; $F_{(16,126)}=2.14, p=0.005$ for dopamine in $B ;$ and $F_{(19,247)}=6.59, p=0.0001$ for glutamate in $C$ and a time $\times$ treatment interaction for $\operatorname{GABA}\left(F_{(16,144)}=2.66 ; p=0.001\right)$, dopamine $\left(F_{(19,190)}=\right.$ $1.89 ; p=0.017)$, or glutamate $\left(F_{(19,247)}=2.07 ; p=0.0063\right) .{ }^{*} p<0.05$ compared with the average of the last three baseline samples using a PLSD post hoc comparison.

Moreover, the increase in extracellular GABA may be derived in part from the functional uncoupling of $\mathrm{GABA}_{\mathrm{B}}$ autoreceptors, perhaps attributable to reduced Ser phosphorylation of the $\mathrm{GABA}_{\mathrm{B} 2}$ receptor subtype.

The origin of extracellular GABA in the accumbens Confirming work by others (for review, see Timmerman and Westerink, 1997), extracellular GABA levels in control subjects were found to be derived primarily from $\mathrm{Na}^{+}$- and $\mathrm{Ca}^{2+}$ insensitive, presumably nonsynaptic, sources. However, the portion of extracellular GABA that was increased after repeated cocaine was exquisitely sensitive to blockade of $\mathrm{Na}^{+}$channels, indicating primarily action potential-dependent, neuronal origin. Moreover, identical slopes in the no-net flux study indicate the involvement of release rather than elimination of GABA in mediating the increased levels (Parsons et al., 1991). Further supporting the role of release mechanisms, repeated cocaine administration does not alter GABA synthesis or presynaptic GABA content in the accumbens (Sorg et al., 1995; Meshul et al., 1998).

There are three potential neuronal sources of extracellular GABA in the accumbens. The majority of the accumbens neurons are medium-sized spiny GABAergic projection cells that possess extensive recurrent collaterals (Smith and Bolam, 1990; Pennartz et al., 1994). In addition, the accumbens contains 5\% mediumsized aspiny GABAergic interneurons. Because these interneurons fire at a relatively high frequency (Kawaguchi et al., 1995), they may also contribute to extracellular GABA. Finally, GABAergic afferents from other brain nuclei, such as the ventral tegmental area, olfactory nucleus, and ventral pallidum, can contribute to extracellular GABA in the accumbens (Brog et al., 1993). Which of these potential sources of extracellular GABA that may be affected by repeated cocaine administration cannot be defined by microdialysis. Although spiny cells are thought to undergo a number of cocaine-induced neuroadaptations that could promote transmitter release, such as increased PKA and calcium/calmodulin-dependent protein kinase II signaling (Gnegy, 2001; Nestler, 2001), electrophysiological studies indicate that the spiny cells may be relatively hyperpolarized and less active after repeated psychostimulant administration (Zhang et al., 1998; Thomas et al., 2001). Although this may signify less contribution by spiny cell recurrent collaterals, cocaine-induced neuroadaptations in dopamine-regulated GABA release in the ventral tegmental area could stimulate the activity of GABAergic neurons projecting to the accumbens (Bonci and Williams, 1996).

\section{Elevating basal extracellular GABA increases tone on $\mathrm{GABA}_{\mathrm{B}}$ presynaptic receptors}

Consistent with functionally significant elevations in extracellular GABA by repeated cocaine, blockade of $\mathrm{GABA}_{\mathrm{B}}$ autoreceptors and heteroreceptors caused an augmented increase in the extracellular levels of GABA, dopamine, and glutamate in the accumbens of cocaine-treated rats. These data not only support the presence of increased GABA tone on $\mathrm{GABA}_{\mathrm{B}}$ receptors but also provide in vivo evidence that the accumulation of extracellular GABA after withdrawal from repeated cocaine can influence near-adjacent heterosynapses to tonically inhibit the release of other neurotransmitters (for review of in vitro evidence, see Isaacson, 2000). Similar to this finding, Giorgetti et al. (2002) recently found that chronic amphetamine treatment increased GABAergic tone on $\mathrm{GABA}_{\mathrm{B}}$ receptors regulating extracellular glutamate and dopamine in the ventral tegmental area. These studies suggest that increased GABA release could be a relatively prevalent feature of psychostimulant abuse and offers an explanation for the widespread reduction in basal metabolic activity produced in brain by repeated psychostimulants in both experimental ani- 
A GABA

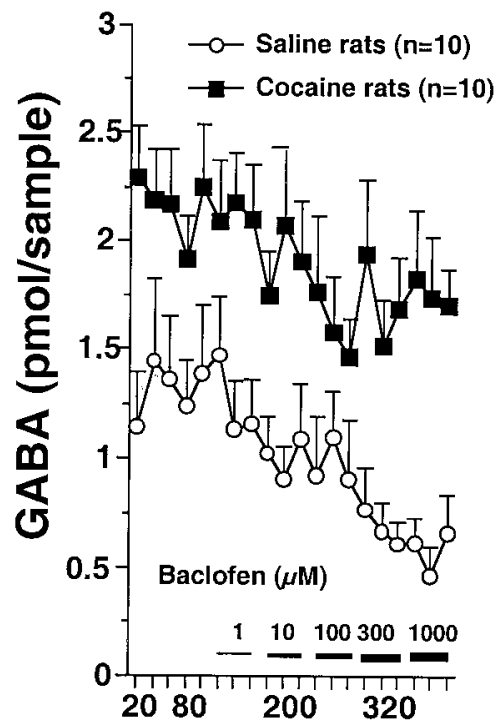

B Dopamine

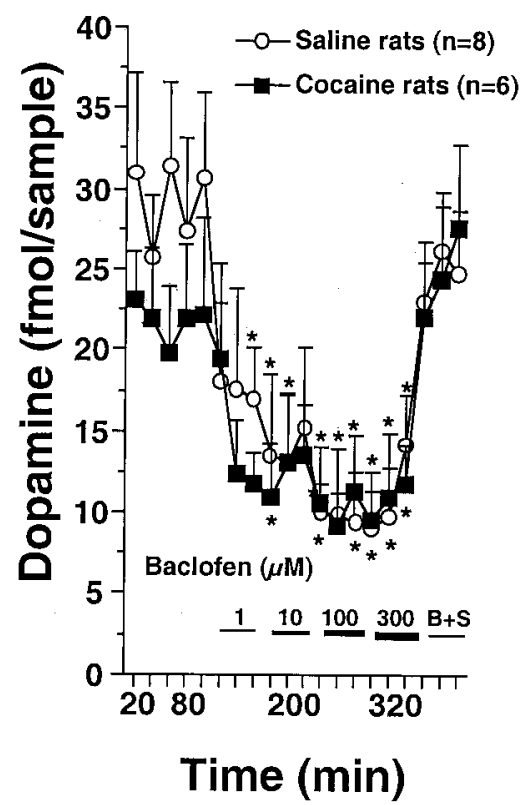

C Glutamate

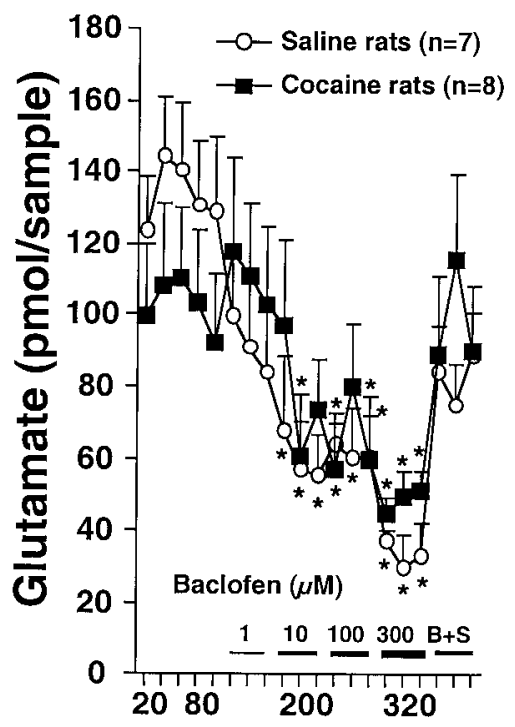

Figure 4. Effects of activation of $\mathrm{GABA}_{\mathrm{B}}$ receptors by reverse dialysis of baclofen on nucleus accumbens levels of $\mathrm{GABA}$, dopamine, and glutamate in chronic saline- and cocaine-treated rats. Increasing concentrations of baclofen were added to the dialysis buffer, and, in some experiments, $300 \mu \mathrm{m} 2-0 \mathrm{H}$-saclofen was added to the final concentration of baclofen to block the stimulation of $G_{A B A}$ receptors $(B+S)$. $A$, Baclofen produced parallel effects on $G A B A$ in both treatment groups. A two-way ANOVA with repeated measures showed a significant difference between treatment (chronic saline vs cocaine; $\left.F_{(1,13)}=15.45 ; p=0.0017\right)$ and over dose $\left(F_{(16,208)}=2.03 ; p=0.0128\right)$ but no time $\times$ treatment interaction $\left(F_{(16,208)}=0.373 ; p=0.987\right)$. $B$, Baclofen significantly decreased extracellular dopamine levels in both groups of rats. A two-way ANOVA with repeated measurement shows a significant difference 0 ver dose $\left(F_{(17,204)}=8.05 ; p=0.0001\right)$ but no difference between treatments $\left(F_{(1,12)}=0.48 ; p=0.51\right)$ or a time $\times$ treatment interaction $\left(F_{(17,204)}=0.654 ; p=0.845\right)$. C, Baclofen similarly decreased extracellular glutamate levels in both the saline- and cocaine-treated groups. A two-way ANOVA with repeated measurements shows a significant difference over dose $\left(F_{(19,247)}=5.42 ; p=0.0001\right)$ but no effect of treatment $\left(F_{(1,13)}=\right.$ $0.1 ; p=0.98)$ or the time $\times$ treatment interaction $\left(F_{(19,247)}=1.09 ; p=0.366\right)$. ${ }^{*} p<0.05$ compared with the average of the last three of the five baseline samples.

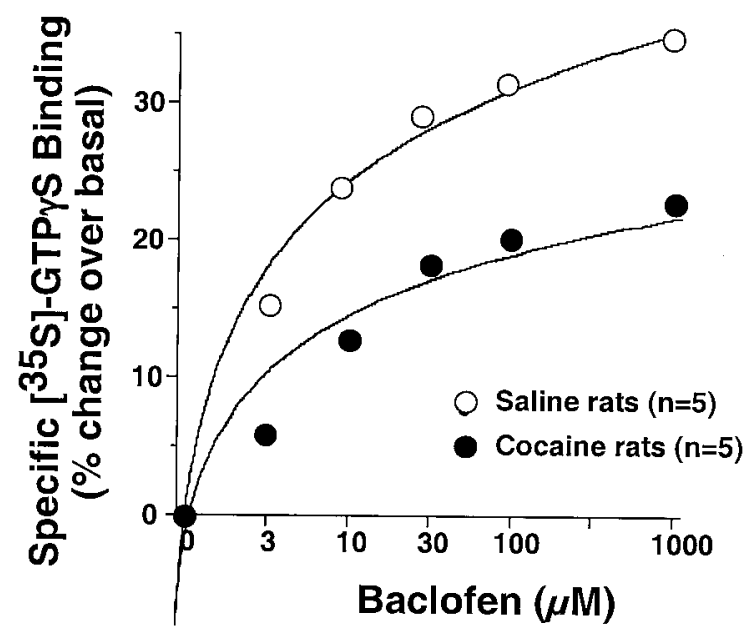

Figure 5. Chronic cocaine treatment decreased the baclofen-stimulated [ $\left.{ }^{35} \mathrm{~S}\right] \mathrm{GTP} \gamma \mathrm{S}$ binding to $\mathrm{G}$-proteins in the nucleus accumbens. A two-way ANOVA with repeated measurements revealed a significant effect of repeated cocaine treatment $\left(F_{(5,40)}=2.79 ; p=0.029\right)$.

mals and human addicts (Volkow et al., 1993; Breiter et al., 1997; London et al., 1999).

Although the enhanced capacity of $\mathrm{GABA}_{\mathrm{B}}$ receptor blockade to elevate extracellular $\mathrm{GABA}$ indicates that the $\mathrm{GABA}_{\mathrm{B}}$ receptors are functional and may not be desensitized, repeated or prolonged exposure to agonist often desensitizes the responsiveness of G-protein-coupled receptors by altering receptor density, conformation, or trafficking (for review, see Tsao and von Zastrow, 2000; Ferguson, 2001). The present study demonstrated a de- crease in baclofen-stimulated $\left[{ }^{35} \mathrm{~S}\right] \mathrm{GTP} \gamma \mathrm{S}$ binding in the accumbens that was associated with increased extracellular GABA levels. This observation is consistent with the finding that repeated amphetamine caused a reduction in $\mathrm{GABA}_{B}$ coupling to $\mathrm{G}_{\mathrm{i} \alpha}$ in the nucleus accumbens, indicating that $\mathrm{GABA}_{\mathrm{B}}$ receptors may be desensitized (Zhang et al., 2000). The total protein content of $\mathrm{GABA}_{\mathrm{B} 1}$ or $\mathrm{GABA}_{\mathrm{B} 2}$ receptors was unaltered in the cocaine group, indicating that changes in overall protein synthesis or degradation are not mediating the apparent desensitization. Similarly, a previous study found no significant alteration in $\mathrm{GABA}_{\mathrm{B} 1}$ receptor protein in repeated cocaine-treated rats ( $\mathrm{Li}$ et al., 2001). However, $\mathrm{GABA}_{\mathrm{B} 1}$ forms a heterodimer with $\mathrm{GABA}_{\mathrm{B} 2}$ to make an active receptor (Bowery and Enna, 2000), and, although $\mathrm{p}-\mathrm{GABA}_{\mathrm{B} 1}$ protein could not be detected in either the saline or cocaine treatment groups, a marked reduction in the amount of $\mathrm{p}-\mathrm{GABA}_{\mathrm{B} 2}$ was measured in the cocaine group.

Reduced Ser phosphorylation of $\mathrm{GABA}_{\mathrm{B} 2}$ after repeated cocaine

Reduced Ser phosphorylation of $\mathrm{GABA}_{\mathrm{B}}$ receptors by PKA or PKC has been shown to both promote (Kamatchi and Ticku, 1990; Taniyama et al., 1992) and desensitize (Couve et al., 2002) $\mathrm{GABA}_{\mathrm{B}}$ receptor-mediated effects. The present findings are most consistent with the study by Couve et al. (2002) demonstrating that dephosphorylation of Ser892 in the cytoplasmic tail of $\mathrm{GABA}_{\mathrm{B} 2}$ mediates desensitization of $\mathrm{GABA}_{\mathrm{B}}$ receptor coupling to $\mathrm{K}^{+}$channels and that $\mathrm{GABA}_{\mathrm{B}}$ agonists inhibit PKA, thereby promoting $\mathrm{GABA}_{\mathrm{B}}$ dephosphorylation and desensitization. Thus, the increase in extracellular GABA after cocaine withdrawal would be expected to decrease $\mathrm{p}-\mathrm{GABA}_{\mathrm{B} 2}$ and thereby desensitize 
A GABA $_{\text {B2 }}$

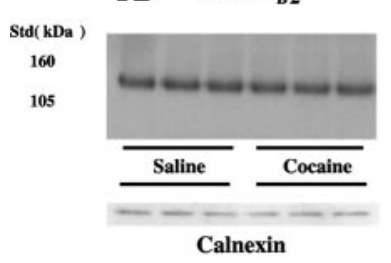

C GABA в2 Band Densities
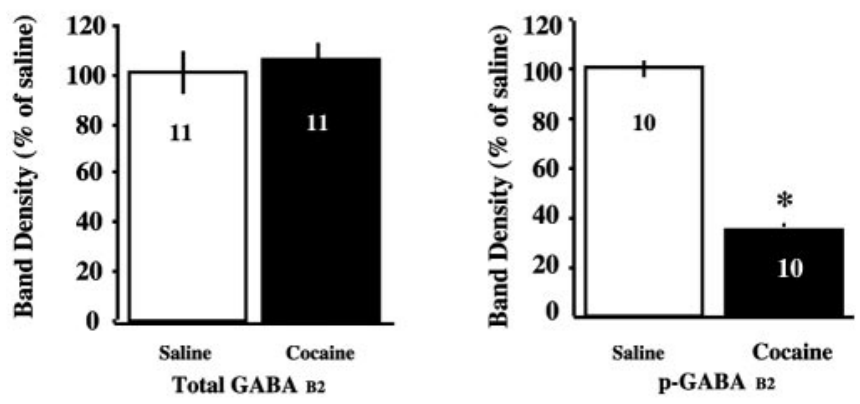

D GABA в1 in Accumbens

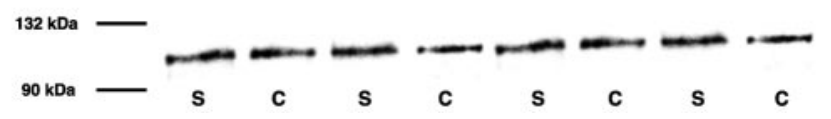

Figure 6. Cocaine treatment reduced $\mathrm{p}-G A B A_{B 2}$ without altering total $G A B A_{B}$ proteins. $A$, Representative immunoblots of $G A B A_{B 2}$ total protein and reprobing for the loading control calnexin. $B$, Representative immunoblot of $p-G A B A_{B 2}$ proteins using the same tissue as in $A$. The bottom blot is the top blot after incubation with phosphatase that eliminated immunoreactive staining of phosphorylated protein. C, Mean \pm SEM percentage change from saline for total $G A B A_{B 2}$ and $p-G A B A_{B 2}$. D, Representative immunoblots of $G A B A_{B 1}$ total protein showing no difference between treatment groups. ${ }^{*} p<0.05$ comparing saline with cocaine treatment groups using a two-tailed Student's $t$ test.

baclofen stimulation of GTP $\gamma \mathrm{S}$ binding and presynaptic transmitter release. These data appear contradictory to the general consensus that repeated psychostimulant administration increases PKA signaling (for review, see Nestler, 2001). However, it is possible that the intracellular microdomain in the vicinity of $\mathrm{GABA}_{\mathrm{B}}$ receptors may not reflect whole-cell PKA activity. For example, an upregulation of whole-cell PKA by chronic cocaine may facilitate vesicular GABA release (Greengard et al., 1993; Trudeau et al., 1996), providing a source of the increased GABA tone on $\mathrm{GABA}_{\mathrm{B}}$ autoreceptors. However, $\mathrm{GABA}_{\mathrm{B}}$ receptors are $\mathrm{G}_{\mathrm{i}}$ coupled, and increased tone on $\mathrm{GABA}_{\mathrm{B}}$ receptors will inhibit $P K A$ in the vicinity of the receptor, thereby reducing $G_{A B A}$ receptor phosphorylation, desensitizing $\mathrm{GABA}_{\mathrm{B}}$ receptors, and further facilitating GABA release.

\section{Repeated cocaine effects on $\mathrm{GABA}_{B}$ heteroreceptors}

Although the GTP $\gamma S$ binding assay cannot distinguish between $\mathrm{GABA}_{\mathrm{B}}$ autoreceptors and heteroreceptors, the dialysis study indicates that, similar to autoreceptors, the heteroreceptors regulating extracellular glutamate and dopamine levels are affected by repeated cocaine. Thus, akin to GABA autoreceptors, the cocaine-induced elevation in extracellular GABA provided increased GABAergic tone on heteroreceptors regulating glutamate and dopamine release. In one of the experiments, the basal levels of extracellular glutamate were reduced after repeated cocaine. A reduction in extracellular glutamate in the accumbens after re- peated cocaine has been previously reported (Pierce et al., 1996; Bell et al., 2000; Hotsenpillar et al., 2001), and blocking GABA $_{\mathrm{B}}$ receptors appeared to normalize the levels of glutamate in cocaine animals to the levels measured in saline animals (Fig. 3C). Basal extracellular glutamate content is derived primarily from the exchange of extracellular cystine with intracellular glutamate (Baker et al., 2002), posing the possibility that $\mathrm{GABA}_{\mathrm{B}}$ receptors may regulate extracellular glutamate in part by inhibiting cystine-glutamate exchange. Indeed, the activity of the exchanger is inhibited by reducing PKA activity (Baker et al., 2002).

\section{Conclusions}

After 3 weeks of withdrawal from repeated cocaine administration, there is an increase in extracellular GABA in the nucleus accumbens that is derived primarily from neuronal sources. The elevated extracellular GABA provides a corresponding increase in tone to $\mathrm{GABA}_{\mathrm{B}}$ autoreceptors and heteroreceptors that regulates the extracellular levels of GABA, glutamate, and dopamine. The increased tone to $\mathrm{GABA}_{\mathrm{B}}$ receptors decreases $\mathrm{p}-\mathrm{GABA}_{\mathrm{B} 2}$, which may account for the desensitization of $G_{A B A}$ receptors, and contributes to the previously observed decrease in basal extracellular levels of glutamate in the accumbens of cocaine-treated animals (Pierce et al., 1996; Bell et al., 2000; Hotsenpillar et al., 2001). Decreased striatal $\mathrm{GABA}_{\mathrm{A}}$ receptor function or subunit composition has also been induced by repeated cocaine in some (Peris, 1996; Suzuki et al., 2000) but not all (Goeders, 1991) studies. This poses the possibility that increased extracellular GABA may downregulate $\mathrm{GABA}_{\mathrm{A}}$ as well as $\mathrm{GABA}_{\mathrm{B}}$ receptor function. Given the integral role in addiction that has been postulated for neuroadaptations in accumbens GABAergic spiny cells (Nestler, 2001; Everitt and Wolf, 2002), the elevation of extracellular GABA and corresponding impact on neurotransmission regulated by $\mathrm{GABA}_{\mathrm{B}}$ receptors may constitute a functionally important step in the development or expression of behaviors associated with psychostimulant addiction.

\section{References}

Baker DA, Xi Z-X, Shen H, Swanson CJ, Kalivas PW (2002) The primary source and neuronal function of in vivo extracellular glutamate. J Neurosci 22:9134-9141.

Bell K, Duffy P, Kalivas PW (2000) Context-specific enhancement of glutamate transmission by cocaine. Neuropsychopharmacology 23:335-344.

Bonci A, Williams JT (1996) A common mechanism mediates long-term changes in synaptic transmission after chronic cocaine and morphine. Neuron 16:631-639.

Bowery NG, Enna SJ (2000) $\gamma$-Aminobutyric acidB receptors: first of the functional metabotropic heterodimers. J Pharmacol Exp Ther 292:2-7.

Breiter HC, Gollub RL, Weisskoff RM, Kennedy DN, Makris N, Berke JD, Goodman JM, Kantor HL, Gasfriend DR, Riorden JP, Mathew RT, Rosen BR, Hyman SE (1997) Acute effects of cocaine on human brain activity and emotion. Neuron 19:591-611.

Brog JS, Salyapongse A, Deutch AY, Zahm DS (1993) The patterns of afferent innervation of the core and shell in the "accumbens" part of the rat ventral striatum: immunohistochemical detection of retrogradely transported fluoro-gold. J Comp Neurol 338:255-278.

Couve A, Thomas P, Calver AR, Hirst WD, Pangalos MN, Walsh FS, Smart TG, Moss SJ (2002) Cyclic AMP-dependent protein kinase phosphorylation facilitates GABAB receptor-effector coupling. Nat Neurosci 5:415-424.

Everitt BJ, Wolf ME (2002) Psychomotor stimulant addiction: a neural systems perspective. J Neurosci 22:3312-3320.

Ferguson SS (2001) Evolving concepts in G protein-coupled receptor endocytosis: the role in receptor desensitization and signaling. Pharmacol Rev 53:1-24. Rev.

Giorgetti M, Hotsenpiller G, Froestl W, Wolf ME (2002) In vivo modulation of ventral tegmental area dopamine and glutamate efflux by local 
GABAB receptors is altered after repeated amphetamine treatment. Neuroscience 109:585-595.

Gnegy ME (2001) $\mathrm{Ca}^{2+} /$ calmodulin signaling in NMDA-induced synaptic plasticity. Crit Rev Neurobiol 14:91-129.

Goeders NE (1991) Cocaine differentially affects benzodiazepine recptoers in discrete regions of rat brain: persistence and potential mechanisms mediating these effects. J Pharmacol Exp Ther 259:574-581.

Greengard P, Valtorta F, Czernik AJ, Benfenati F (1993) Synaptic vesicle phosphoproteins and regulation of synaptic function. Science 259:780-785.

Harsing LG, Zigmond MJ (1997) Influence of dopamine on GABA release in striatum: evidence for D1-D2 interactions and non-synaptic influences. Neuroscience 77:419-429.

Hotsenpiller G, Giorgetti M, Wolf ME (2001) Alterations in behaviour and glutamate transmission following presentation of stimuli previously associated with cocaine exposure. Eur J Neurosci 14:1843-1855.

Isaacson JS (2000) Synaptic transmission: spillover in the spotlight. Curr Biol 10:R475-R477.

Kamatchi GL, Ticku MK (1990) Functional coupling of presynaptic GABAB receptors with voltage-gated $\mathrm{Ca}^{++}$channel: regulation by protein kinase $\mathrm{A}$ and $\mathrm{C}$ in cultured spinal neurons. Mol Pharmacol 38:342-347.

Kawaguchi Y, Wilson CJ, Augood SJ, Emson PC (1995) Striatal interneurons: chemical physiological and morphological characterization. Trends Neurosci 18:527-535.

Li J, Olinger AB, Dassow MS, Abel MS (2001) GABA(B) receptor gene expression is not altered in cocaine-sensitized rats. J Neurosci Res 68:241-247.

London ED, Bonson KR, Ernst M, Grant S (1999) Brain imaging studies of cocaine abuse: implications for medication development. Crit Rev Neurobiol 13:227-242.

Meshul CK, Noguchi K, Emre N, Ellison G (1998) Cocaine-induced changes in glutamate and GABA immunolabeling within rat habenula and nucleus accumbens. Synapse 30:211-220.

Nestler EJ (2001) Molecular basis of long-term plasticity underlying addiction. Nat Rev Neurosci 2:119-128.

Parsons LH, Smith AD, Justice Jr JB (1991) Basal extracellular dopamine is decreased in the rat nucleus accumbens during abstinence from chronic cocaine. Synapse 9:60-65.

Paxinos G, Watson C (1986) The rat brain in stereotaxic coordinates. New York: Academic.

Pennartz CM, Groenewegen HJ, Lopes da Silva FH (1994) The nucleus accumbens as a complex of functionally distinct neuronal ensembles: an integration of behavioural, electrophysiological and anatomical data. Prog Neurobiol 42:719-761.

Peris J (1996) Repeated cocaine injections decrease the function of striatal GABAA receptors. J Pharmacol Exp Ther 276:1002-1008.

Pierce RC, Bell K, Duffy P, Kalivas PW (1996) Repeated cocaine augments excitatory amino acid transmission in the nucleus accumbens only in rats having developed behavioral sensitization. J Neurosci 16:1550-1560.

Robinson TE, Whishaw IQ (1988) Normalization of extracellular dopamine in striatum following recovery from a partial unilateral 6-OHDA lesion of the substantia nigra: a microdialysis study in freely moving rats. Brain Res 450:209-224.

Schaffhauser H, Cai Z, Hubalek F, Macek TA, Pohl J, Murphy TJ, Conn PJ (2000) cAMP-dependent protein kinase inhibits mGluR2 coupling to G-proteins by direct receptor phosphorylation. J Neurosci 20:5663-5670.
Schoffelmeer A, Vanderschuren L, De Vries T, Hogenboom F, Wardeh G, Mulder A (2000) Synergistically interacting dopamine D1 and NMDA receptors mediate nonvesicular transporter-dependent GABA release from rat striatal medium spiny neurons. J Neurosci 20:3496-3503.

Sesack SR, Pickel VM (1990) In the rat medial nucleus accumbens, hippocampal and catecholaminergic terminals converge on spiny neurons and are in apposition to each other. Brain Res 527:266-279.

Shoji S, Simm D, McDaniel WC, Gallagher JP (1997) Chronic cocaine enhances $\gamma$-aminobutyric acid and glutamate release by altering presynaptic and not postsynaptic gamma-aminobutyric acid $_{\mathrm{B}}$ receptors within the rat dorsolateral septal nucleus. J Pharmacol Exp Ther 280:129-137.

Sim LJ, Selley DE, Dworkin SI, Childers SR (1996) Effects of chronic morphine administration on mu opioid receptor-stimulated $\left[{ }^{35} \mathrm{~S}\right] \mathrm{GTP} \gamma \mathrm{S}$ autoradiography in rat brain. J Neurosci 16:2684-2692.

Smith AJ, Bolam JP (1990) The neural network of the basal ganglia as revealed by the study of synaptic connections of identified neurons. Trends Neurosci 13:259-265.

Sorg BA, Guminski BJ, Hooks MS, Kalivas PW (1995) Cocaine alters glutamic acid decarboxylase differentially in the nucleus accumbens core and shell. Brain Res Mol Brain Res 29:381-386.

Suzuki T, Abe S, Yamaguchi M, Bab A, Hori T, Shiraishi H, Ito T (2000) Effects of cocaine administration on receptor binding and subunits mRNA of GABAA-benzodiazepine receptor complexes. Synapse $38: 198-215$.

Taniyama K, Niwa M, Kataoka Y, Yamashita K (1992) Activation of protein kinase $\mathrm{C}$ suppresses the $\gamma$-aminobutyric acid B receptor-mediated inhibition of the vesicular release of noradrenaline and acetylcholine. J Neurochem 58:1239-1244.

Thomas MJ, Beurrier C, Bonci A, Malenka RC (2001) Long-term depression in the nucleus accumbens: a neural correlate of behavioral sensitization to cocaine. Nat Neurosci 4:1217-1223.

Timmerman W, Westerink BHC (1997) Brain microdialysis of GABA and glutamate: what does it signify? Synapse 27:242-261.

Trudeau LE, Emery DG, Haydon PG (1996) Direct modulation of the secretory machinery underlies PKA-dependent synaptic facilitation in hippocampal neurons. Neuron 17:789-797.

Tsao P, von Zastrow M (2000) Downregulation of G protein-coupled receptors. Curr Opin Neurobiology 10:365-369.

Vanderschuren LJ, Kalivas PW (2000) Alterations in dopaminergic and glutamatergic transmission in the induction and expression of behavioral sensitization: a critical review of preclinical studies. Psychopharmacology 151:99-120.

Volkow ND, Fowler JS, Wang GJ, Hitzemann R, Logan J, Schyler DJ, Dewey SL, Wolf AP (1993) Decreased dopamine D2 receptor availability is associated with reduced frontal metabolism in cocaine abusers. Synapse 14:167-177.

White FJ, Kalivas PW (1998) Neuroadaptations involved in amphetamine and cocaine addiction. Drug Alcohol Depend 51:141-154.

Wolf ME (1998) The role of excitatory amino acids in behavioral sensitization to psychomotor stimulants. Prog Neurobiol 54:679-720.

Zhang K, Tarazi FI, Campbell A, Baldessarini RJ (2000) GABA(B) receptors: altered coupling to G-proteins in rats sensitized to amphetamine. Neuroscience 101:5-10.

Zhang XF, Hu XT, White FJ (1998) Whole-cell plasticity in cocaine withdrawal: reduced sodium current in nucleus accumbens neurons. J Neurosci 18:488-498. 